Лазарець Мирослава

бакалавр психології, здобувач освітнього рівня «магістр» психолого-природничого факультету, Рівненського державного гуманітарного університету http://orcid.org/0000-0002-6874-700X DOI https://doi.org/10.35619/praprv.v1i15.191

\title{
ЯВИЩЕ САМОТНОСТІ ЯК ПРОЯВ СОЦАЛЬНОГО НЕПРИЙНЯТТЯ
}

Анотація. У статті автор здійснює спробу розкрити особливості самотності як прояву соиіального неприйняття. Особливу увагу приділено аналізові феномену самотності, який має давню історію і супроводжує людство на кожному етапі його існування.

Стаття присвячена критеріям аналізу природі самотності, яка поділяється на два основні наукові підходи, які розглядають иэю категорію як індивідуальне та соціальне явище. Самотність як індивідуальне явище сприяе самовдосконаленню особистості шляхом втечі від реальності. Представлено різні сучасні класифікаџії соиіального самотності, розроблені як вітчизняними, так $і$ зарубіжними авторами. За Вайсом, засновник інтеракціоністського підходу у дослідженні феномену «самотності», який вводить такі поняття, як "емоиійна самотність" та "сочіальна самотність". У його працях дане явище трактується як "стан, викликаний відсутністю близької інтимної прихильності". За Садлером, які представлені у нерозривному зв'язку: космічний; культурний; соиіальний; міжособистісний. За I. С. Коном, який пропонує таку класифікацію самотності:тимчасове почуття самотності та супутній пригнічений настрій; ситуативна самотність, яка залежить від життєвих обставин; хронічна.

Увага акцентується на причинах, особливостях соціального самотності за Боумен, який висунув три причини збільшення самотності в сучасному світі:ослаблення зв'язків у первинній групі;підвищена мобільність сім'ї;підвищена сочіальна мобільність. Та проаналізовано заступні класифікачіі причин самотності за Дерлега та Маргулісом, Вайсом, Шагівалєєвой. Зроблено висновки в системі вивчення самотності як прояву неприйняття, шуо дане явища провокує самотність індивіда або самоізоляиію, цей процес $\epsilon$ невід'ємним елементом проходження соиіалізащії індивіда при соиіальній взаємодії та прочесах життєдіяльності групи. Подальший розгляд иієї проблеми вбачаємо в більш розгорнутому вивченні основних функціональних впливів сочіального неприйняття, щзо виникають при загрозі приналежності, неоднозначності, невизначеності ситуачій $і$ відмови у взаєминах; дослідженні взаємозалежності неприйняття та соиіальної самотності.

Ключові слова: індивідуальна самотність, соціальна самотність, соціальні відносини, самотність, неприйняття, соціальна ізолячія.

Постановка проблеми. Самотність - одна 3 найактуальніших соціальних проблем, що зачіпають первісні основи соціальної взаємодії. Феномен самотності має давню історію і супроводжує людство на кожному етапі його існування. У цьому випадку самотність буває різних типів і різного ступеня прояву. Вчення про природу самотності поділяються на два основні наукові підходи, які розглядають цю категорію як індивідуальне та соціальне явище. Самотність як індивідуальне явище сприяє самовдосконаленню особистості шляхом втечі від реальності. В даний час зазначений тип самотності не втрачає своєї актуальності, наприклад, у духовних практиках. Дуальність поглядів на проблему феномена, що вивчається, має наступні прояви: 3 одного боку, вчені розглядають це як позитивне явище в житті особистості (самотність як детермінанта творчої діяльності - Романова, Дробишевський), 3 іншого боку, розглядають його як негативний персонаж - як причину руйнування особистості. 
Самотність як складне соціальне явище є об'єктом дослідження у філософії, психології, соціології, антропології, соціальній філософії та інших науках, щодає змогу підтверджувати актуальність обраної теми в контексті розгляду проблеми самотності як прояву соціального неприйняття.

Аналіз останніх досліджень 3 проблеми. В даний час поняття "самотність" має велику кількість різних тлумачень. Р. Вайс розглядає самотність як «стан, спричинений відсутністю близької інтимної прихильності». В останньому філософському словнику самотність трактується як «стан і почуття людини, яка перебуває в умовах реальної або уявної комунікативної депривації», тобто в стані ізоляції від суспільства, в результаті чого відчувається розрив соціальних зв'язків, відчуття невдоволення від спілкування тощо.

Садлер пов'язує міжособистісну самотність із втратою глибокого спілкування з іншим індивідом. Неможливість будувати стосунки в процесі спілкування, встановлювати близькі відносини з іншими призводить до цього типу самотності. Романова та Осинський позначуть самотність як типове явище, характерне для найширших i найрізноманітніших верств населення. Визначаючи спектр сучасних поглядів на вказане соціальне явище, його прояви у вигляді тенденцій самоізоляції в середовищі сучасності та його функціональне наповнення, поведінкові прояви, є потреба деталізувати деякі аспекти явища самотності як прояву соціального неприйняття.

Мета статті - висвітлити особливості явища самотності як прояву соціального неприйняття, ситуацію його прояву в контексті сучасних теорій вивчення.

Відповідно до мети, було сформульовано такі завдання: висвітлити основні погляди на явище самотності; систематизувати сучасні класифікації соціального самотності, розроблені як вітчизняними, так і зарубіжними авторами; розкрити причини та особливості соціальної самотності.

Виклад основного матеріалу дослідження. Багато вчених робили спроби дослідити природу самотності. Всі знання та вчення про самотність в даний час можна розділити на два основні наукові підходи при вивченні явища самотності - як індивідуального та соціального феномену (Гольман 2008). Спочатку дане явище було - абстрактною філософською категорією, яке позначало спосіб втечі від реальності 3 метою вдосконалення себе. Самотність несла творчий принцип людської душі. Певною мірою це послужило появі такого психологічного методу, як самоаналіз.

На початку XX ст. суспільство пострадянського простору стало свідком значних трансформацій, що супроводжуються соціально-економічними трансформаціями, зміною усталених психологічних стереотипів та ціннісних орієнтацій особистості, що призвело до різних наслідків, зокрема, проблема самотності як прояву соціального неприйняття набула особливої значущості. Голман зазначає, що становлення ринкових відносин, формування інституту приватної власності супроводжувалися бурхливим розладом соціальних відносин, психології та масової свідомості соціуму, що призвело до деформації самосвідомості населення, та масштабних проявів соціального неприйняття окремих індивідів визначеними групами. Особливість соціального самотності полягає в тому, що як особистість, так і цілі прошарки суспільства розривають зв'язки із середовищем, в якому і завдяки якому тривало їхня життєдіяльність, при усвідомленні себе повноправними членами суспільства (Гольман 2008). Психоемоційна напруга, що виявляється в динаміці масової свідомості, відображає процес наростання соціальної самотності: посилення страху, усвідомлення безсилля, втрата зв'язку з суспільством.

Самотність як досвід є наслідком ряду причин об’єктивного та суб'єктивного характеру, що залежать як від мікросередовища, так і від макросередовища (Грицанов 2003). На думку Романової, Осинського, ХХ ст. позначає соціологічний підхід до вивчення самотності, трактуючи це як "типове явище, характерне для найширших i найрізноманітніших верств населення" (Романова 2004). Самотність як наслідок соціального неприйняття - $€$ негативним явищєм сучасного суспільства та активно вивчається в працях західних філософів та психологів. Окрім поглибленого вивчення природи соціальної 
самотності, вчені наводять інші типи самотності, які можна трактувати як окремі прояви цього стану, так і як різновид соціальної ізоляції.

Вайс, засновник інтеракціоністського підходу у дослідженні феномену «самотності» (Рогова 2000), вводить такі поняття, як "емоційна самотність" та "соціальна самотність". У його працях дане явище трактується як "стан, викликаний відсутністю близької інтимної прихильності". Вайс визначив соціальну самотність як «відсутність доступного кола спілкування та задоволення соціальних зв'язків. Почуття вигнання, неприйняття тощо основні форми його вираження. Цей тип самотності болючий i супроводжується різноманітними негативними емоціями - почуттям нудьги, смутку, туги, відчаю, пригніченості, жалості до себе, неприйняття, неповноцінності тощо» (Михайлова 2012: 145).

У процесі вивчення вищезазначеного явища західні вчені висунули безліч класифікацій, що визначають його суть. Садлер висунув чотири виміри самотності, які представлені у нерозривному зв'язку: космічний; культурний; соціальний; міжособистісний. Космічний вимір самотності позначає відчуження індивіда у світі, сенс існування на землі, віру в долю тощо. Культурна самотність проявляється в осіб, які відчувають, що їхній зв'язок із власною культурною спадщиною розірваний або загальновизнана культура неприйнятна для їх внутрішнього світу (Eisenberger 2003: 290 - 292). Соціальний та міжособистісний виміри феномену - спрямовані на зв'язки, стосунки та взаємодію індивідів та груп. Таким чином, ми зупинимось на аналізі останніх двох видів вимірювання самотності. Вчені трактують соціальна самотність так: поняття «соціальне» застосовується насамперед до особливих груп у суспільстві, а не до суспільства в цілому. Цей тип самотності включає такі форми часткової соціальної ізоляції, як позбавлення членства в групі, неприйняття групою. В результаті, поки індивід переживає соціальну самотність, їі самосприйняття набуває негативних відтінків: з'являється відчуття неприйняття, непрацездатності та марності. Соціальній самотності можуть сприяти такі фактори, як роздробленість суспільства поряд із зростаючою соціалізацією, невизначеність традиційних соціальних кордонів, розпад традиційних груп та їх короткого життя, групи 3 ієрархією соціальних позицій, а також чіткий розподіл ролей у них (Blackhart 2009: 269 - 309). Садлер пов'язує міжособистісну самотність із втратою глибокого спілкування 3 іншим індивідом. Неможливість будувати стосунки в процесі спілкування, встановлювати близькі відносини 3 іншими призводить до цього типу самотності.

Іншу позицію у визначенні поняття «самотність» та його класифікації можна побачити в роботі американських дослідників Перлмана та Пепло «Лабіринти самотності» (Шагівалєва, 2007). Вчені висунули вісім теоретичних підходів до вивчення явищ, класифікованих за такими групами: психодинамічний, феноменологічний, екзистенційний, соціологічний, інтеракціоністичний, когнітивний, інтимний та системно-теоретичний (Hartgerink, 2014).

У контексті цього дослідження найбільш цікавими $є$ соціологічний, інтимний, інтеракціоністський підходи. Представниками соціологічного підходу є Боуман, Рісман, Слейтер, Романова, Осінський (Рогова 2000). Боумен висунув три причини збільшення самотності в сучасному світі: ослаблення зв'язків у первинній групі; підвищена мобільність сім'ї; підвищена соціальна мобільність. Такі вчені, як Дерлега та Маргуліс, по-різному трактують поняття «самотність». «Інтимність» та «саморозкриття» - ключові поняття в інтерпретації явища самотності. Відповідно до розвитку теорії Р. Вайса, вони припускали, що соціальні відносини сприяють досягненню особистості різними реальними цілями.

Самотність обумовлена відсутністю відповідного соціального партнера, який міг би сприяти досягненню цих цілей. Феномен може провокувати відсутність в міжособистісних стосунках особи близькості, необхідної для конфіденційного спілкування.

Інтеракціоністська точка зору представлена Вайсом (Кон 2007). Досліджуючи природу самотності, вчений визначив дві причини появи цього явища:

с - самотність як продукт інтерактивного впливу фактору особистості або фактору 
- $\quad$ розгляд питання самотності щодо соціальних відносин, таких як прихильність, керівництво та оцінка, тобто самотність як результат відсутності соціальної взаємодії особистості, яка задовольняє основні соціальні потреби особистості.

Залежно від різниці афективних реакцій Вайс виділив два типи самотності:

- емоційна самотність в результаті відсутності близької інтимної прив'язки, наприклад, любовної чи сімейної. Емоційно самотня людина відчувє неспокій, занепокоєння та порожнечу;

- соціальна самотність як відповідь на відсутність значущих дружніх стосунків чи почуття спільності. Соціально самотня людина відчуває тугу та відчуття соціальної маргінальності або соціального неприйняття. Таким чином, зауважимо, що зарубіжні вчені, досліджуючи суть самотності, відзначали їі соціальну природу.

У даний час в вітчизняній науці також зростає інтерес до вивчення явища самотності, як прояву соціального неприйняття який, на думку Ж.В. Пузанова, пов'язаний із посиленням індивідуалізму, ослабленням зв'язків первинної соціальної групи та класовою роздробленістю всередині суспільства (Hymel2015: 293 - 299).

Інтерпретація самотності як соціального явища вказується в різних сучасних класифікаціях цього поняття. Наприклад, Шагівалєєва, на підставі дослідження характеристик досвіду студентів-самітників, виділяє такі причини самотності (Шагівалєва 2007).

1. Причини, що пов'язані із особливостями суб'єкта: свідоме і цілеспрямоване бажання індивіда бути самотнім; б) схильність до самотності через наявність певних рис характеру, які перешкоджають спілкуванню, іпідтримка тісних стосунків 3 людьми.

2. Причини, що походять від інших осіб (незнання, уникнення, вимушене ув'язнення тощо).

3. Причини, що виникають в результаті збігу обставин (об'єктивна ізоляція, незалежна ні від самого індивіда, ні від групи).

Ялом представляє класифікацію самотності залежно від типу ізоляції:

- спричинені соціальною ізоляцією - відсутність доступного кола спілкування осіб, здатних задовольнити потребу у спілкуванні як такому, в міжособистісних контактах;

- спричинені емоційною ізоляцією - через відсутність прив'язаності до конкретної людини або коли людина відокремлює свої емоції від спогадів про подію та стає нездатною до близьких стосунків з іншими людьми(Gerber 2009: 468 - 488).

Конпропонує таку класифікацію самотності:

- тимчасове почуття самотності та супутній пригнічений настрій як природне явище людського життя; кожна людина здатна випробувати таке почуття;

- ситуативна самотність, яка залежить від життєвих обставин: різка зміна умов життя та соціального кола (зміна місця проживання, навчання чи роботи), поява незадоволеної потреби в любові, втрата близьких, охолодження або розпад колись значущих особистих стосунків тощо з часом така самотність зазвичай проходить, поступаючись місцем новим стосункам та емоційним прив'язаностям;

- хронічне самотність, переслідування індивіда постійно і сприймається нею як властивість власного характеру (Кон 2007).

Отже, слід зазначити, що в даний час існує багато зарубіжних та вітчизняних наукових досліджень 3 проблеми самотності як прояву соціального неприйняття, що дозволяє поглянути на досліджуване явище з різних сторін. Романова, Осінський, автори монографії «Самотні жінки», зазначають, що «філософи багато і по-різному говорили про явище самотності по відношенню до індивіда взагалі, але практично не вивчали його 3 позицій чоловічі та жіночі принципи ..., лише у XX ст. позначає соціологічний підхід до вивчення самотності, який полягає в трактуванні цього явища як типового явища, характерного для найширших і найрізноманітніших верств населення» (Романова 2000). 
У даний час велика кількість робіт присвячена аналізу явища самотності як прояву соціального неприйняття. Дослідники в галузі психології розробляють перелік причин самотності, а також шляхи придушення цього почуття. Так, наприклад, П. П. Пономарьов (Романова 2004) виділяє дві групи причин, чому індивід обираю самоізоляцію. Перша група - це патологічні, тобто причини, пов'язані 3 тією чи іншою негативною деформацією особистості або патологією. Друга група - причини екзистенційного характеру.

Серед патологічних причин виділено такі: неадекватна самооцінка; слабкі комунікативні навички контактів 3 іншими людьми; наявність соціальної фобіі; психопатологія; наявність співзалежності; інфантилізм.

Екзистенційні причини самоізоляції полягають у сприйнятті самотності як норми, 3 одного боку, та, як джерело збагачення суб'єкта корисними та цінними ресурсами, з іншого. У зв'язку з цим виділяються такі причини самотності:

- самотність як елемент духовного зростання;

- самотність як вид субкультури, прийнятний для суб'єкта;

- самотність, приховування поведінки, несхваленої суспільством;

- самотність як елемент самодостатності особистості;

- самотність як частина професії суб'єкта.

У роботі «Лабіринти самотності» Рук, Пепло та Янг визначаючи перспективи допомоги одиноким, пов'язують між собою такі поняття, як «самотність», «депресія» та пропонують методи когнітивної терапії (Покровський 2003).

Висновки i перспективи подальших розвідок.Теоретичний аналіз аспектів самотності як прояву соціального неприйняття дозволив обгрунтувати поняття «самотності», яке використовується для позначення категорії, яка має досить складний $\mathrm{i}$ суперечливий характер. У сучасній науці існує багато визначень цього явища, які дають можливість охарактеризувати його як «стан соціальної ізоляції». Аналізуючи теоретичні відомісті, що висвітлюють цю проблему, досліджено, що соціальна самотність $є$ наслідком економічних перетворень, які торкнулися суспільство в цілому, і тому інтерес науковців зосередився на вивченні цього явища. В даний час самотність вивчається з різних точок зору: наводяться причини самотності, розробляються класифікації, підходи, виділяються ознаки самотності.

На основі узагальнення стану розроблення проблеми показано, що самотність як соціальне явище відбувається насправді як відповідь на триваючі соціально-економічні, політичні та інші трансформації, оскільки крім творчих моментів вони мають і деструктивні наслідки, такі як індивідуалізм, урбанізація, послаблення міжособистісних відносин, розрив традицій і т. д. це нездатність окремої людини, а іноді і цілої соціальної групи, пристосуватися до швидко мінливих ритмів життя, що сприяє посиленню почуття самотності, що, в свою чергу, є свого роду " захист "від триваючих і постійних соціальноісторичних подій.

Виявлено, що соціальне неприйняття провокує самотність індивіда або самоізоляцію, цей процес є невід'ємним елементом проходження соціалізації індивіда при соціальній взаємодії та процесах життєдіяльності групи. Подальший розгляд цієї проблеми вбачаємо в більш розгорнутому вивченні основних функціональних впливів соціального неприйняття, що виникають при загрозі приналежності, неоднозначності, невизначеності ситуацій i відмови у взаєминах; дослідженні взаємозалежності неприйняття та соціальної самотності.

\section{СПИСОК ПОСИЛАНЬ}

Гольман, Т. И. (2008). Социальное одиночество студенческой молодежи в переходном обществе: управленческий аспект. Новосибирск.

Грицанов, А. А. (2003). Новейший философский словарь. Минск.

Кон, И. С. (2007). Дружба. Этико-психологический очерк. Москва: Политиздат.

Покровский, Н. Е. (2003). Лабиринты одиночества. Москва: Прогресс. 
Михайлова, А. И. (2012). Отцовство как новый тип родителей в контексте научных знаний. Вестник ЗабГУ, 12, 145.

Рогова, Е. Е. (2011). Одиночество в условиях современного общества. Краснодар.

Романова, Н. П., \& Дробышевский, В. С. (2004). Терапия одиночества или терапия одиночества? Москва: ЧитГУ.

Романова, Н. П., \& Осинский, И. (2000). Одинокие женщины: потребности, жизненные ориентации и пути их реализации. Москва: ЧитГТУ.

Шагивалева, Г. Р. (2007). Одиночество и особенности его опыта студентами. Елабуга: Альмедиа.

Blackhart, G. C., Nelson, B. C., Knowles, M. L. \& Baumeister, R. F. (2009). Rejection elicits emotional reactions but neither causes immediate distress nor lowers self-esteem: A metaanalytic review of 192 studies on social exclusion. Personality and Social Psychology Review, 13,269-309.

Eisenberger, N. I., Lieberman, M. D., \& Williams, K. D. (2013). Does rejection hurt? An fMRI study of social exclusion. Science, 302,290-292.

Gerber, J., \& Wheeler, L. (2009). On being rejected: A meta-analysis of experimental research on rejection. Perspectives on Psychological Science,4,468-488.

Hartgerink, C., Beest, I., Wicherts, J., \& Williams, K. (2014). Ordinal effects of ostracism: A meta-analysis of Cyberball studies. Unpublished Manuscript: Tilburg University.

Hymel, S., \& Susan, M. (2015). Four Decades of Research on School Bullying: An Introduction. American Psychologist, 70,293-299.

\section{REFERENCES}

Golman, T. I. (2008). Sotsial'noye odinochestvo studencheskoy molodezhi v perekhodnom obshchestve: upravlencheskiy aspekt [Social loneliness of student youth in a transitional society: the managerial aspect]. Novosibirsk. [in Russian].

Gritsanov, A. A. (2003). Noveyshiy filosofskiy slovar'. [The latest philosophical dictionary]. Minsk. [in Russian].

Con, I. S. (2007). Druzhba. Etiko-psikhologicheskiy ocherk [Friendship. Ethical and psychological essay]. Moskva: Politizdat. [in Russian].

Mikhailova, A. I. (2012). Ottsovstvo kak novyy tip roditeley v kontekste nauchnykh znaniy [Parenthood as a new type of parents in the context of scientific knowledge]. Vestnik ZabGU, 12, 145. [in Russian].

Pokrovsky, N. E. (2003). Labirinty odinochestva [Labyrinths of loneliness]. Moskva: Progress. [in Russian].

Rogova, E. E. (2011). Odinochestvo v usloviyakh sovremennogo obshchestva [Loneliness in modern society]. Krasnodar.[in Russian].

Romanova, N. P., \& Osinsky, I. I. (2000). Odinokiye zhenshchiny: potrebnosti i zhiznennyye oriyentatsii $i$ puti ikh realizatsii [Single women: needs, life orientations and ways of their realization]. Moskva: ChitGTU. [in Russian].

Romanova, N. P., \& Drobyshevsky, V. S. (2004). Terapiya odinochestva ili terapiya odinochestva? [Loneliness therapy or loneliness therapy?]. Moskva: ChitGU.[in Russian].

Shagivaleva, G. R. (2007). Odinochestvo i osobennosti yego opyta u studentov [Loneliness and features of his experience by students].Yelabuga: Almedia. [in Russian].

Blackhart, G. C., Nelson, B. C., Knowles, M. L., \& Baumeister, R. F. (2009). Rejection elicits emotional reactions but neither causes immediate distress nor lowers self-esteem: A metaanalytic review of 192 studies on social exclusion. Personality and Social Psychology Review, 13,269-309. [in English].

Eisenberger, N. I., Lieberman, M. D., \& Williams, K. D. (2013) Does rejection hurt? An fMRI study of social exclusion. Science,302,290-292. [in English].

Gerber, J. \& Wheeler, L. (2009). On being rejected: A meta-analysis of experimental research on rejection. Perspectives on Psychological Science,4,468-488. [in English]. 
Hartgerink, C., Beest, I., Wicherts, J., \& Williams, K. (2014). Ordinal effects of ostracism: A meta-analysis of Cyberball studies. Unpublished Manuscript: Tilburg University. [in English].

Hymel, S., \& Susan, M. (2015). Four Decades of Research on School Bullying: An Introduction. American Psychologist, 70,293-299. [in English].

\title{
THE PHENOMENON OF LONELINESS AS A MANIFESTATION OF SOCIAL REJECTION
}

\author{
Myroslava Lazarets \\ bachelor of psychology, \\ VI year student of the Faculty of Psychology and Natural Sciences, \\ Rivne State University for the Humanities \\ http://orcid.org/0000-0002-6874-700X \\ DOI https://doi.org/10.35619/praprv.v1i15.191
}

\begin{abstract}
In the article the author tries to reveal the peculiarities of loneliness as a manifestation of social rejection. Particular attention is paid to the analysis of the phenomenon of loneliness, which has a long history and accompanies humanity at every stage of its existence.

The article is devoted to the criteria of analysis of the nature of loneliness, which is divided into two main scientific approaches, which consider this category as an individual and social phenomenon. Loneliness as an individual phenomenon promotes self-improvement of the individual by escaping from reality.

Various modern classifications of social loneliness, developed by both domestic and foreign authors, are presented. According to $R$. Weiss, the founder of the interactionist approach in the study of the phenomenon of "loneliness", which introduces such concepts as "emotional loneliness" and "social loneliness". In his works, this phenomenon is interpreted as "a condition caused by a lack of close intimate attachment." According to W. Sadler, which are presented in inseparable connection: space; cultural; social; interpersonal. According to IS Kon, who proposes the following classification of loneliness: a temporary feeling of loneliness and the accompanying depressed mood; situational loneliness, which depends on life circumstances; chronic.

Attention is focused on the causes, features of social loneliness according to K. Bowman, who put forward three reasons for the increase in loneliness in the modern world: the weakening of ties in the primary group, increased family mobility, increased social mobility. But the alternative classifications of the causes of loneliness by V. Derleg and S. Margulis, R. Weiss, GR Shagivaleeva are analyzed.

Conclusions are made in the system of studying loneliness as a manifestation of rejection that this phenomenon provokes individual loneliness or self-isolation, this process is an integral part of the socialization of the individual in social interaction and life processes of the group.

We see further consideration of this problem in a more detailed study of the main functional effects of social rejection, which arise when there is a threat of belonging, ambiguity, uncertainty of situations and denial of relationships; study of the interdependence of rejection and social loneliness.
\end{abstract}

Key words: individual loneliness, social loneliness, social relations, loneliness, rejection, social isolation. 